\section{Reducing dropout rate for improved key performance indicators in Dagatan National High School through the implementation of Project SAGIP}

\author{
Manalo, Hazel $\unrhd$ \\ DepEd-San Juan Senior High School, Philippines (hazelymanalo22@gmail.com)
}

Received: 9 December 2020

Available Online: 22 February 2021

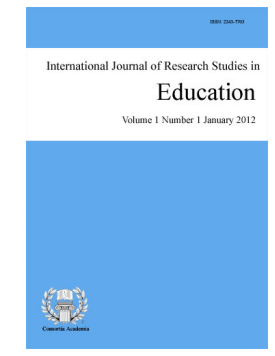

ISSN: 2243-7703 Online ISSN: 2243-7711

OPEN ACCESS

\title{
Abstract
}

One of the major concerns of an educational institution is how to achieve low dropout rate if zeroing it out is not possible. Keeping learners in the school has always been a struggle for educators. This is so because we have a big heart for our students and we presume the role of parents who would give a hundred percent support for the attainment of their children's dreams. This study is a descriptive action research that focuses on the effectiveness of intervention activities and strategies used in combating risk-factors causing high dropout rate through the implementation of Project SAGIP (Save At-Risk Students through Guidance and Intervention Programs). This project was advocated from the author's Project WE CARE for SARDOs which was her first dropout reduction study in the previous school that she served. Project SAGIP however was more intensive as it deemed fit for the school setting and current situation in Dagatan National High School, an integrated JHS-SHS located in Taysan, Batangas which caters to 23 Barangays from the municipalities of Taysan, Lobo, and Batangas City. Specifically, the study intended to identify high- risk factors causing students to dropout from school as per records of class advisers and guidance teachers, and the appropriate intervention activities that had been provided in order to motivate them to continue their studies. Result of the study shows the effectiveness of the interventions and strategies used to solve the problem of the school with regard to high percentage of Students -At-Risk and the increasing number of dropouts, and how the implementation of Project SAGIP also paved way to achieving better results as reflected in our school's Key Performance Indicators (KPI) relative to the decrease in Dropout Rate.

Keywords: students-at-risk; factors; interventions; strategies; dropout reduction; KPIs 


\section{Reducing dropout rate for improved key performance indicators in Dagatan National High School through the implementation of Project SAGIP}

\section{Context and rationale}

Students dropping out of high school are more likely to be unemployed and receive public welfare, and they are at increased risk for mental health problems, gang membership, and criminal behavior (Konnold, 2016). As Valcov (2018) stressed in his research, dropping out of school is a serious academic issue and has important implications for a wide variety of socio-economic and health outcomes. Compared to high school graduates, school dropouts may have greater job instability and economic difficulties. Hence, it is crucial to engage and keep at-risk students to school if we want them to succeed in the future.

In Dagatan National High School, identified students- at- risk in academic, social, and co- curricular activities had been a major problem. As per school records, a lot of students drop out from their classes during the last three (3) consecutive years. There were 27 or $2.16 \%$ dropouts in SY 2016- 2017, 22 or 3.23\% in SY 2017- 2018, and 49 or 3.71\% in SY 2018- 2019. School data on the number of dropouts by cause gathered from interview with students and parents revealed that dropping out is caused by the following risk factors: lack of interest or distractions, poor academic performance including learning disabilities, absenteeism, child labor, early marriage, family problem, and illness.

Having considered the above-mentioned risk factors, the researcher implemented Project SAGIP which aimed to address the problem of high dropout rate through the following intervention activities: (1) Guidance Profiling Survey; (2) Crafting of Student Handbook with emphasis on strict implementation of School Policies and Anti-Bullying Program (3) Adopt- A- Student Program integrated in School- Based Feeding Program; (4) Strengthened Memorandum of Understanding/ Agreement or Kasunduan with parents, and Barangay Captains; (5) Reinforcement and remediation activities during ICL time conducted by SSG Officers and Linguisteen Club; (6) Home Visitation; (7) Recognition, Reward and Incentive System; (8) Modular Delivery of Learning (ADM); (9) Putting up a Suggestion Box; (10) Peer Tutoring/ One-on-one Tutoring with subject teachers and Reading Remediation reinforced by Project 3Bs (Bawat Bata Bumabasa); (11) Providing appropriate intervention programs for challenged students; (12) Boosted implementation of Barkada Kontra Droga (BKD); (13) Bible Study Program; and (14) Enhanced Partnership with Parents thru Numerous Activities.

\section{Review of related literature}

David and Albert (2015), in their research focused on the recent trends in out-of-school children in the Philippines exemplified that the quality of secondary education is challenging because content is much more specialized, and keeping students in secondary schools motivated is probably harder. While in primary school, the problem was largely one of late entry, in secondary school the problem is dropout rates. The solution in primary age OOSC was bringing them into school, the solution for secondary aged OOSC must focus on how to keep them in. As cited in the study of Cornell et al. (2013), Jimerson, Reschly, and Hess concluded that school dropout is better understood as a process of disengagement from school rather than a sudden event. Life events and family problems can be important factors in some cases, but school experiences appear to be the most consistent influence on high school completion. The act of dropping out is a process that appears to begin with the transition to high school.

Three general areas of intervention are recommended as sites to help bring older children the education they need: engaging with the local governments and communities, alternative delivery modes of education (ADM), and proper adherence to conditions laid out in the 4Ps. Older out of school children have dropped out or temporarily ceased schooling either for economic or motivation issues. Most of these are boys who are already 
working or have lost interest. Compared to getting young children into the early grades, this is a more difficult multifaceted challenge (David \& Albert, 2015). Similarly, Valkov (2018) pointed out that positive relationships with parents, involvement with religion and good climate at school and in the student's class are other strategic protective factors that prevent many problems and risk behaviors, including substance use and school dropout. The closer young people's identification with the value system of the religion in which they are being brought up, the fewer risk behaviors they engage in and the lesser their exposition to school and mental health problems as well as to conflicts with the law.

This conviction was supported by Dupere et al. (2015) who emphasized that high school dropout is commonly seen as the result of a long-term process of failure and disengagement. As useful as it is, this view has obscured the heterogeneity of pathways leading to dropout. Research suggests, for instance, that some students leave school not as a result of protracted difficulties but in response to situations that emerge late in their schooling careers, such as health problems or severe peer victimization. Conversely, others with a history of early difficulties persevere when their circumstances improve during high school. Thus, an adequate understanding of why and when students drop out requires a consideration of both long-term vulnerabilities and proximal disruptive events and contingencies. All the contributing factors to disengagement as cited in the above-mentioned studies have a significant relationship with students' performance and dropping out from school. It is undoubtedly difficult for teachers to engage the students in the different activities in the class and only through relevant intervention programs can the problems in their behavioral, emotional, and cognitive development be addressed.

\section{Innovation, intervention, and strategy}

Work plan for Project SAGIP

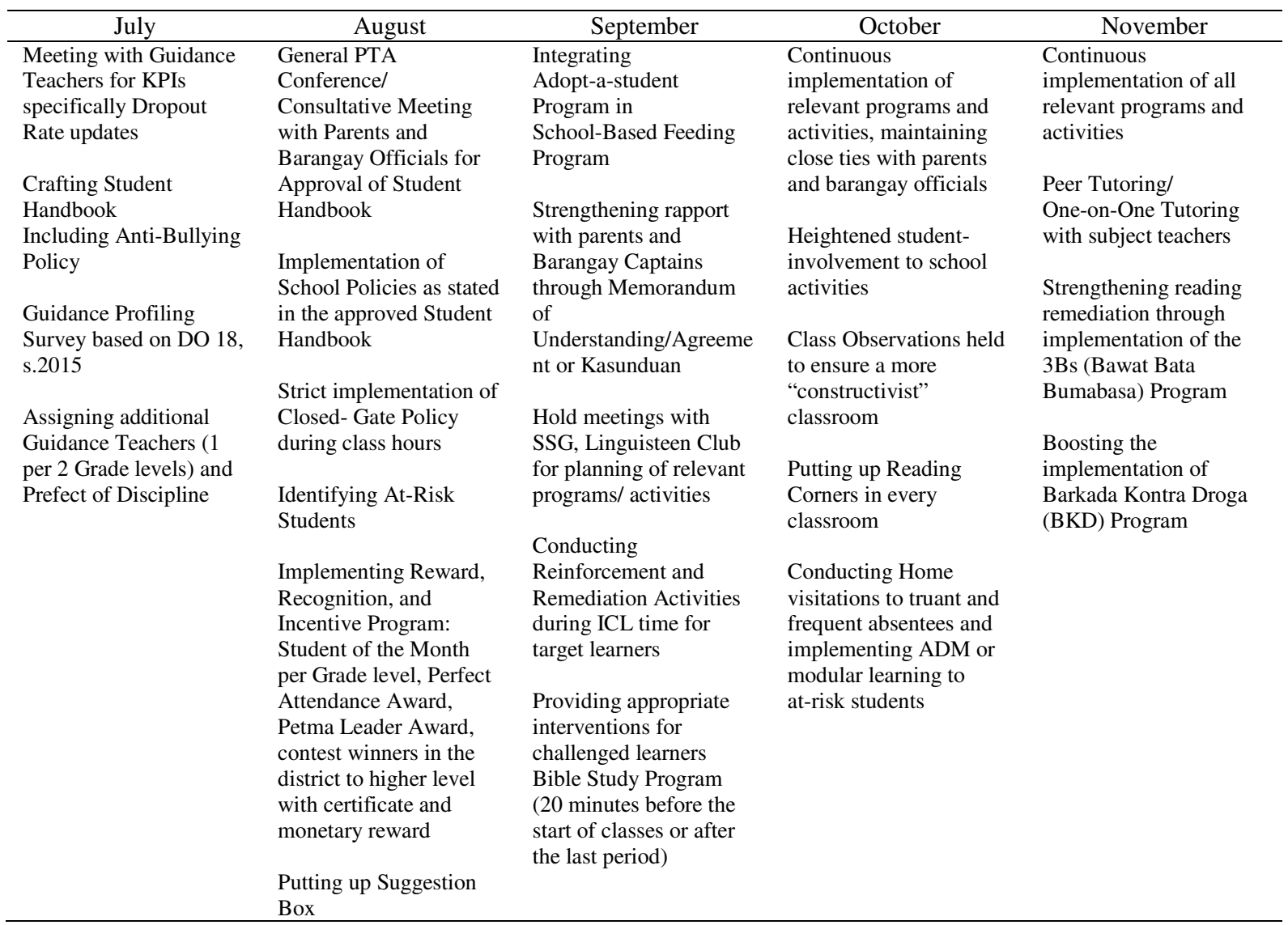




\begin{tabular}{llll}
\hline \multicolumn{1}{c}{ December } & \multicolumn{1}{c}{ January } & \multicolumn{1}{c}{ February } & March \\
\hline $\begin{array}{l}\text { Continuous implementation of } \\
\text { all relevant programs and } \\
\text { activities }\end{array}$ & $\begin{array}{l}\text { Continuous implementation of } \\
\text { all relevant programs and } \\
\text { activities }\end{array}$ & $\begin{array}{l}\text { Continuous implementation of } \\
\text { all relevant programs and } \\
\text { activities }\end{array}$ & $\begin{array}{l}\text { Continuous implementation of } \\
\text { all relevant programs and } \\
\text { activities }\end{array}$ \\
$\begin{array}{l}\text { Observation and random } \\
\begin{array}{l}\text { interview with teachers, } \\
\text { guidance teachers, parents, and } \\
\text { learners }\end{array}\end{array}$ & $\begin{array}{l}\text { Observation and random } \\
\text { interview } \\
\text { with teachers, guidance } \\
\text { teachers, parents, and learners }\end{array}$ & $\begin{array}{l}\text { Observation and random } \\
\text { interview with teachers, } \\
\text { guidance teachers, parents, and } \\
\text { learners }\end{array}$ & $\begin{array}{l}\text { Accomplishing the Project } \\
\text { effectiveness of the Project } \\
\text { implementation }\end{array}$ \\
Parents and Stakeholders' Day & & & $\begin{array}{l}\text { Assessing result of the school's } \\
\text { KPIs }\end{array}$ \\
\hline
\end{tabular}

In continuance of her advocacy of reducing dropout rate through relevant programs for better students' performance, the researcher initiated the implementation of Project SAGIP when she started her service to the school in July. Upon knowing and witnessing the current distressing problems- 49 dropouts from the previous school year, uncontrollable students' behavior, esp. male students who casually jump over the fence or skip through the gate itself by reasoning out to the school guard that teachers sent them to an errand and other lies, cutting classes, smoking and using vape just outside the school premises (in front of the gate, outside a nearby store, inside a barber shop just in front of the school), and bullying cases committed to classmates and teachers reported to the guidance office, she at once studied the school SIP and made some revisions of the AIP to include Priority Improvement Areas. Having found out that there was only one Guidance Teacher assigned for 1,902 students of the current year, she used the ratio 1:500 and added two more coordinators, 1 was assigned in Grade 7-8, 1 in Grade 9-10, and a Social Science teacher for SHS, Grade 11-12. She also assigned a Prefect of Discipline for each as partner in implementing changes in the school.

First step was crafting a Student Handbook for there was no handbook that time, just class policies that depend on the class advisers. The handbook was presented and discussed to parents and barangay officials for consultation. Upon approval, each class was provided with a copy for adviser's discussion with the students and for posting on their classroom wall. Printed copies were also given to parents. The school started the strict implementation of the school policies stated in the handbook including closed-gate policy on class hours, and disciplinary actions for offending students from minor to grave offenses, with barangay officials as our partner. Strategies in keeping at-risk students in school were also done like giving recognition, rewards, and incentives including one-hundred pesos monetary reward, and more opportunities to participate in clubs, and demonstrate talents in school programs that were held after class hours.

Having identified at-risk students through Guidance Profiling Survey and report of advisers and guidance teachers on cases committed, we started home visits, reinforcement and remediation activities, one-on-one tutoring, inclusion in School-Based Feeding Programs, religious (Bible Study Program) and other relevant activities also implemented by the SSG and Linguisteen Club. More so, strengthening our Reading Program through Reading Corners and 3Bs (Bawat Bata Bumabasa), and boosting the Barkada Kontra Droga (BKD) greatly helped in keeping at-risk students in school.

The researcher constantly monitored the implementation of programs and activities relative to Project SAGIP thru regular and follow-up meetings with key teachers, SSG officers and advisers, guidance coordinators, advisers, parents, and barangay officials. As the school head, she also made sure that issues and concerns of the students that they voiced out thru the suggestion box were addressed. To foster spirit of camaraderie with the parents and stakeholders, the school also ensured their involvement to various activities such as the Parents and Stakeholders' Day, Nagkakaisang ZUMBAyanan, and the Grand Alumni Homecoming in celebration of the $50^{\text {th }}$ Founding Anniversary of the school. All the above-mentioned activities as indicated in the Work Plan for Project SAGIP were done as deemed relevant with the aim of reducing dropout rate and improving other Key Performance Indicators. 


\subsection{Action research questions}

This study purposively aimed to highlight the effectiveness of intervention activities and programs under Project SAGIP in Dagatan National High School. Specifically, it sought to answer the following questions:

$>\quad$ What are the distinct features of intervention activities that suit the needs and learning of identified students- at- risk?

How may these intervention activities contribute to the success of Project SAGIP in reducing Dropout Rate which is among the identified Priority Improvement Areas of the school?

$>\quad$ How effective are the intervention activities to at-risk students' performance as reflected in other Key Performance Indicators (KPIs) of the school?

\section{The action research}

This research was primarily conducted to promote positive student behavior and reduce challenging behaviors through intervention activities under the Project SAGIP (Save At-Risk students through Guidance and Intervention Program). The study covered the distinct features and effectiveness of intervention activities apt for the identified Students at Risk based from anecdotal records and reports of class advisers, subject teachers, and guidance coordinators of Dagatan National High School.

\subsection{Participants and/or other sources of data and information}

\section{Table 1A}

Identified students-at- risk of dropping out in junior high school as filed in the guidance office

\begin{tabular}{lcccccc}
\hline \multicolumn{1}{c}{ Identified Students-At-Risk and Cases } & G7 & G8 & G9 & G10 & Kabuuan & Porsyento \\
\hline Mababang marka & 12 & 31 & 18 & 5 & 66 & 14.28 \\
Kawalan ng interes sa pag-aaral & 10 & 0 & 0 & 10 & 20 & 4.32 \\
Negatibo pakikisalamuha & 2 & 0 & 0 & 0 & 2 & 0.43 \\
Bayolenteng pag-uugali & 6 & 0 & 0 & 0 & 6 & 1.30 \\
Inabanduna & 0 & 0 & 0 & 1 & 1 & 0.22 \\
Pagbubuntis & 0 & 0 & 0 & 2 & 2 & 0.43 \\
Kakulangan sa salapi & 15 & 0 & 0 & 3 & 18 & 3.90 \\
Late comers & 12 & 23 & 13 & 10 & 58 & 12.55 \\
Madalas liban & 21 & 30 & 17 & 19 & 87 & 18.83 \\
Nagka-problema sa pamilya & 3 & 1 & 3 & 3 & 10 & 2.16 \\
Nagtatrabaho habang napasok & 0 & 5 & 3 & 8 & 16 & 3.46 \\
Nagkasakit & 2 & 1 & 0 & 0 & 3 & 0.65 \\
May boyfriend & 0 & 15 & 3 & 17 & 35 & 7.58 \\
Cutting Class & 1 & 21 & 11 & 12 & 45 & 9.74 \\
Natalon sa bakod & 9 & 17 & 12 & 1 & 39 & 8.44 \\
Kabuuan & 114 & 155 & 85 & 108 & 408 & 100 \\
\hline
\end{tabular}

\section{Table 1B}

Identified students-at- risk of dropping out in senior high school as filed in the guidance office

\begin{tabular}{|c|c|c|}
\hline Case & No. of Students SHS Grade 11-12 & Percentage \\
\hline Panununtok/Suntukan & 12 & 8.23 \\
\hline Drugs & 1 & .68 \\
\hline Bullying & 30 & 20.54 \\
\hline Pasalitang Pambabastos & 8 & 5.48 \\
\hline Pagsusugal ng Pitik & 10 & 6.85 \\
\hline Pagtalon sa Bakod & 14 & 9.60 \\
\hline Kalaswaan & 1 & .68 \\
\hline Pagbabanta & 2 & 1.37 \\
\hline Pananapok & 3 & 2.05 \\
\hline Cutting Classes & 20 & 13.70 \\
\hline Paninigarilyo & 25 & 17.12 \\
\hline Pagmumura at Pagbabanta & 20 & 13.70 \\
\hline Total & 146 & $100 \%$ \\
\hline
\end{tabular}


Manalo, H.

Table 1-A and Table 1-B show the number and percentage of students who were considered at-risk due to a number of reasons like violating school policies, absenteeism, lack of interest and distractions, truancy or cutting classes, poor academic performance including learning disabilities, poverty, family problem, child labor, and illness. It can be gleaned from the above tables that there were 408 students in Junior High School (Grade 7-10), and 146 students from Senior High School (Grade 10-12) with a total of 554 students who were identified as at-risk. These were the students who became the target of our re-engagement programs and activities in order to save them from dropping out. In JHS, "Madalas Liban" or frequent absenteeism ranked No.1 with 87 students or $18.83 \%$ followed by "Mababang Marka" or Poor Academic Performance with 66 students or $14.48 \%$ while in SHS, Bullying is a leading cause for disciplinary action with 30 students or $20.54 \%$ followed by "Paninigarilyo" or Smoking with 25 students or $17.12 \%$.

Re-engaging identified students-at- risk is in academic, social, and co-curricular activities are a major problem in our school. From SY 2016 to 2019, a lot of students drop out from their classes. School data on the number and rate of dropouts by cause showed that there were 27 dropouts or $2.16 \%$ in SY 2016-2017; 22 or $3.23 \%$ during SY 2017-2018; and 49 or 3.71\% in SY 2018- 2019. Interview with students and parents revealed that dropping out is caused by the following reasons: lack of interest/ distractions, poor academic performance, poverty, child labor, early marriage, family problem, and illness. In addition, the prevalence of slow readers, students with poor comprehension, and students with learning disabilities can also be attributed to this number.

Having identified these at-Risk Students, the researcher prepared a Work Plan that includes proposed interventions and strategies for students' engagement.

\subsection{Data gathering methods}

This study was designed to re-engage identified students at-risk in different school academic, social and cocurricular activities through intervention and relevant programs. At- risk students were identified based on the anecdotal records of class advisers and those filed in the Guidance Office for those who have committed a number of cases of misbehavior, truancy, and/or absenteeism. Previous records, descriptive field notes of interview with the parents during Home Visitation were also checked. Interventions were done to address the problem in focus, how these may help the respondents in performing well in their class and the effectiveness of each intervention in honing the character of each student involved were the main concern of the study.

Qualitative research technique by Savin-Baden and Major (2013) was utilized in this study and data were collected through interviews and observations. This action research technique is a broad inquiry method that uses unstructured data-collection methods, such as focus groups, observations, or documents (Ary et al., 2010). Also, records from the Guidance Office served as bases for identifying At-Risk Students and the proper intervention activities to be done. In order to observe the implementation of Project SAGIP, a Project Monitoring Report Form was accomplished by the researcher. Results were analyzed and the findings served as bases for developing methodologies that will aid in decreasing high dropout rate.

\section{Table 2}

Project monitoring report form based on School Improvement Plan (SIP) Priority Improvement Areas (PIA)

\begin{tabular}{|c|c|c|c|c|}
\hline Name of Project & $\begin{array}{c}\text { Project Objectives } \\
\text { and Targets }\end{array}$ & Date of Monitoring & $\begin{array}{l}\text { Accomplishments/ } \\
\text { Status to date }\end{array}$ & $\begin{array}{c}\text { Issues/ Problems/ } \\
\text { Challenges }\end{array}$ \\
\hline \multirow[t]{2}{*}{$\begin{array}{l}\text { Project SAGIP } \\
\text { (Save At-Risk Students } \\
\text { through Guidance and } \\
\text { Intervention Programs) }\end{array}$} & $\begin{array}{l}\text { To reduce the annual } \\
\text { dropout rate with an } \\
\text { average of } 3.23 \% \text { to at } \\
\text { least } 2 \% \text { in } 3 \text { years }\end{array}$ & $7 / 30 / 2020$ & $\begin{array}{l}\text { PIAs were identified, } \\
\text { PTA and other } \\
\text { stakeholders were } \\
\text { informed of the program }\end{array}$ & $\begin{array}{l}\text { Dropout rate is } \\
\text { noticeably increasing } \\
\text { annually }\end{array}$ \\
\hline & & $8 / 19 / 2016$ & $\begin{array}{l}\text { Students who are at- } \\
\text { risk of dropping out due } \\
\text { to poor attendance, } \\
\text { academic, financial, and } \\
\text { behavioral difficulties } \\
\text { were identified. }\end{array}$ & $\begin{array}{l}\text { A total of } 554 \text { students } \\
\text { were identified to be at- } \\
\text { risk of dropping out due } \\
\text { to lack of interest/ } \\
\text { distractions, family } \\
\text { problem, financial } \\
\text { constraint, and others }\end{array}$ \\
\hline
\end{tabular}


Reducing dropout rate for improved key performance indicators in Dagatan National High School

Table 2 ...continued

\begin{tabular}{|c|c|c|c|c|}
\hline \multirow[t]{7}{*}{ Name of Project } & $\begin{array}{c}\text { Project Objectives } \\
\text { and Targets }\end{array}$ & Date of Monitoring & $\begin{array}{c}\text { Accomplishments/ } \\
\text { Status to date }\end{array}$ & $\begin{array}{c}\text { Issues/ Problems/ } \\
\text { Challenges }\end{array}$ \\
\hline & & August- February & $\begin{array}{l}\text { Alternative Delivery } \\
\text { Mode (ADM) had been } \\
\text { strengthened, modules } \\
\text { in different learning } \\
\text { areas were designed, } \\
\text { students with academic } \\
\text { difficulties were tutored } \\
\text { by their teachers and } \\
\text { peers. }\end{array}$ & $\begin{array}{l}\text { Insufficient learning } \\
\text { materials, lack of } \\
\text { parents' support }\end{array}$ \\
\hline & & July- March & $\begin{array}{l}\text { Students at- risk but } \\
\text { with special abilities } \\
\text { were engaged to } \\
\text { different clubs or groups } \\
\text { where they can share } \\
\text { their talents and skills } \\
\text { and would feel } \\
\text { motivated. }\end{array}$ & $\begin{array}{l}\text { Lack of encouragement } \\
\text { and opportunities to } \\
\text { expose their talents }\end{array}$ \\
\hline & & August- March & $\begin{array}{l}\text { Students with excellent } \\
\text { performance and } \\
\text { behavior were given } \\
\text { recognition and } \\
\text { monetary rewards } \\
\text { monthly. }\end{array}$ & $\begin{array}{l}\text { Source of fund for } \\
\text { monetary rewards }\end{array}$ \\
\hline & & September- March & $\begin{array}{l}\text { Barkada Kontra Droga } \\
\text { (BKD), Teach } \\
\text { One-Each One Program } \\
\text { of the SSG, Bible Study } \\
\text { Program, and other } \\
\text { relevant activities were } \\
\text { implemented }\end{array}$ & Parental support \\
\hline & & August- December & $\begin{array}{l}\text { Barangay Captains } \\
\text { and/or other officials } \\
\text { frequently visit the } \\
\text { school to assist in } \\
\text { solving conflicts/ } \\
\text { implement sanctions for } \\
\text { offenses }\end{array}$ & $\begin{array}{l}\text { Availability of the } \\
\text { barangay captain }\end{array}$ \\
\hline & & July- November & $\begin{array}{l}\text { Financially challenged } \\
\text { students were included } \\
\text { in the School- based } \\
\text { feeding Program }\end{array}$ & $\begin{array}{l}\text { Some students were } \\
\text { reluctant to join the } \\
\text { feeding program }\end{array}$ \\
\hline
\end{tabular}

Table 3 shows the updated status of implementation of an Identified Priority Improvement Area stated in the School Improvement Plan (SIP). It could be gleaned from the Project Monitoring Report Form that with the continuous implementation of the programs and activities, the objectives of Project SAGIP will be realized.

\subsection{Discussion of results and reflection}

After the implementation of relevant programs and activities specifically for Students-At-Risk, the following data reveal the results and implications of Project SAGIP particularly in reducing Dropout Rate and improving other KPIs.

\section{Table 4}

Guidance report

\begin{tabular}{llccc}
\hline \multicolumn{1}{c}{$\begin{array}{c}\text { Grade Level } \\
2019-2020\end{array}$} & $\begin{array}{c}\text { No. of Dropouts } \\
\text { (Sections with Dropouts only) }\end{array}$ & $\begin{array}{c}\text { No. of Home } \\
\text { Visitation }\end{array}$ & $\begin{array}{c}\text { No. of Students } \\
\text { with Disciplinary } \\
\text { Action }\end{array}$ & $\begin{array}{c}\text { No. of Appearance } \\
\text { (Brgy. } \\
\text { Captain/Brgy. } \\
\text { Officials }\end{array}$ \\
\hline $\begin{array}{l}\text { Grade } 7 \\
\text { (10 sections) }\end{array}$ & $\begin{array}{l}\text { Magalang- 1 } \\
\text { Masunurin- } 1 \\
\text { Matulungin- } 1\end{array}$ & 6 & 10 & 7 \\
& TOTAL- 3 & & \\
\hline
\end{tabular}


Manalo, $\mathrm{H}$.

Table 4 ...continued

\begin{tabular}{|c|c|c|c|c|}
\hline $\begin{array}{l}\text { Grade Level } \\
2019-2020\end{array}$ & $\begin{array}{c}\text { No. of Dropouts } \\
\text { (Sections with Dropouts only) }\end{array}$ & $\begin{array}{l}\text { No. of Home } \\
\text { Visitation }\end{array}$ & $\begin{array}{l}\text { No. of Students } \\
\text { with Disciplinary } \\
\text { Action }\end{array}$ & $\begin{array}{c}\text { No. of Appearance } \\
\text { (Brgy. } \\
\text { Captain/Brgy. } \\
\text { Officials }\end{array}$ \\
\hline $\begin{array}{l}\text { Grade } 8 \\
\text { (9 sections) }\end{array}$ & $\begin{array}{l}\text { Apitong- 1 } \\
\text { Ipil- 1 } \\
\text { Mahogany- 1 } \\
\text { Narra- 1 } \\
\text { Yakal- 1 } \\
\end{array}$ & 5 & 32 & 54 \\
\hline $\begin{array}{l}\text { Grade } 9 \\
\text { ( } 8 \text { sections })\end{array}$ & $\begin{array}{l}\text { Atis- } 1 \\
\text { Dalandan- } 2 \\
\text { Mangga-1 } \\
\text { Pomelo-1 }\end{array}$ & 3 & 27 & 20 \\
\hline $\begin{array}{l}\text { Grade } 10 \\
\text { (7 sections) }\end{array}$ & $\begin{array}{l}\text { Carnation- } 1 \\
\text { Ilang Ilang- } 2 \\
\text { Sunflower- } 1 \\
\text { Sampaguita-1 } \\
\text { TOTAL- } \quad 5 \\
\end{array}$ & 6 & 4 & 9 \\
\hline $\begin{array}{l}\text { Grade } 11 \\
\text { (7 sections) }\end{array}$ & TOTAL -0 & 10 & 19 & 14 \\
\hline $\begin{array}{l}\text { Grade } 12 \\
(9 \text { sections })\end{array}$ & $\begin{array}{l}\text { SMAW 12-3 Carnelian- } 2 \\
\text { TOTAL - } 1\end{array}$ & 13 & 22 & 14 \\
\hline
\end{tabular}

Table 4 presents the number of dropouts in SY 2019-2020 which obviously decreased to a high extent. It also reports the initiatives done in order to successfully gain the desired outcome such as home visitation, disciplinary actions given, and strong partnership with stakeholders, our barangay officials.

Table 5

Dropout by cause in S.Y. 2019-2020

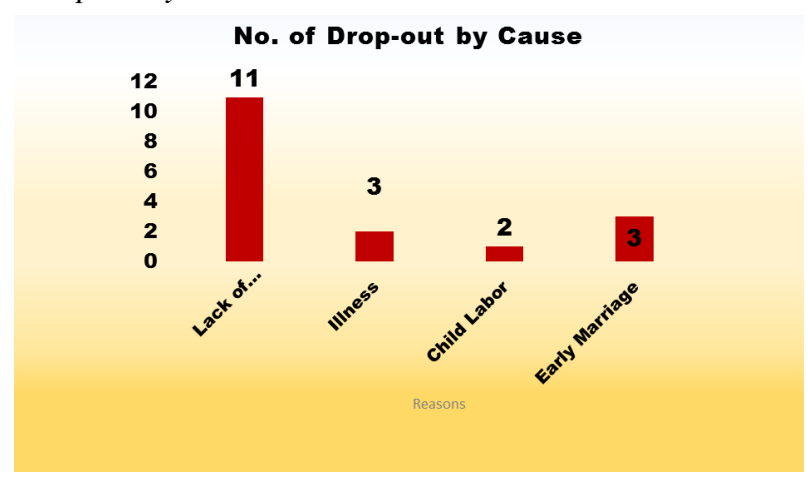

Table 5 reveals that the interventions and strategies used to address the problem proved to be very effective as shown in the above table. After the completion of the project in March 2020, only 19 students dropped out from school due to lack of interest, illness, child labor, and early marriage. The reasons were broken down into four (4) as compared with the eight (8) reasons stated in reports on the number and reasons of dropout during the three previous school years: 2016-2017,2017-2018, 2018-2019 which were lack of interest/ distractions, poor academic performance, poverty, child labor, early marriage, family problem, and illness.

\section{Findings}

\subsection{Intervention activities that suit the needs of students-at- risk}

Intervention activities and materials that were done relative to the implementation of Project SAGIP are discussed here with respect to the problem manifested by the students involved. 


\section{$\underline{\text { Intervention Materials }}$}

Profiling survey with the guidance teacher - The guidance teachers were in charge of collecting previous records of the students involved using the Profiling and Initial Risk Assessment Tool for Children-at- Risk (DO 18, S. 2015).

Home visitation form - This is used as tool for teacher's home visit observation and agreement form between teacher and parents of the concerned students.

Office referral - The teacher writes up a referral documenting the student's misbehavior and sends both the referral and students to the guidance office for intervention. The student stays in the guidance office where he continues his studies through activities given by the teachers until such time that he could again be admitted to mainstream class.

Agreement (kasunduan) - The student and his parent sign an agreement form that outlines the specific activities that the student is to engage in depending on his offense and as stated in the Student Handbook. This form is also signed by the Barangay Captain/ Officials as guarantors, and by the teacher, guidance teacher, and school principal.

\section{$\underline{\text { Intervention Activities/Programs }}$}

Adopt-a- student program - Identified challenged students due to financial difficulties were recommended for inclusion in the School-Based Feeding Program. These students were also taught entrepreneurship in HE class so that they could earn some money to support their other needs.

Student of the month - A student from each grade level will be chosen as Student of the Month. The criteria set for determining the student does not include academic performance but focused on proper decorum- honesty, politeness, helpfulness, willfulness, kindness. The Student of the Month is recognized during flag ceremony with certificate and one hundred pesos (Php 100.00).

Reward and incentive program - A student who wins 1st place in contests and competitions in the district level, area level, division level as well as his/ her coach will be recognized during flag ceremony and will receive one hundred pesos (Php 100.00). The same amount is given to students who unexpectedly exhibited outstanding behavior such as returning a wallet and other valuable things or commended by other people or group in the community for his/her good deed.

Strengthened reading program thru reading corner and 3Bs implementation - Our love for our dear learners whom we consider our "angels" in school made us innovate specifically in implementing our Reading Program. As a result, most students moved from frustration to independent levels in both Word Recognition (55 to 195), and Comprehension (26 to 175).

Each one, teach one - This is a special program initiated by the Supreme Student Government (SSG) that aims to help students who are lagging behind in class, especially in Mathematics. Student who excels in class is assigned one student to teach. Also, they hold special classes during ICL time for remediation activities.

Boosted Barkada Kontra Droga - With the belief that students are motivated when they feel they "belong", our SSG led the implementation of BKD. It was very successful that our SSG President was awarded as one of the Regional Outstanding Learner on Drug Prevention Advocacy Program.

\subsection{Success of Project SAGIP}

The interventions and strategies used to address the problem proved to be very effective. After the completion of the project in March 2020, only 19 students dropped out from school compared with the 49 dropouts in the previous school year. 


\section{DROP-OUT RATE}



Dropout Rate of Dagatan National High School for the last three years (SY 2017-2014, SY 2017-2018, and SY 2018-2019) or before the implementation of the project had been relatively high and increasing due to several factors. After all the action steps were done relative to the implementation of Project SAGIP, it can be gleaned that from $3.71 \%$ dropout rate or 49 students who dropped out in S.Y. 2018- 2019, it was reduced to a great extent with $1.01 \%$ or only 19 students in S.Y. 2019-2020.

\subsection{Effectiveness of Project SAGIP as reflected in other KPIs}

The success of Project SAGIP in reducing dropout rate can also be attributed to the better results of our other Key Performance Indicators such as increased Retention Rate, Completion Rate, and Graduation Rate, and decreased Failure Rate as reflected in the following charts.

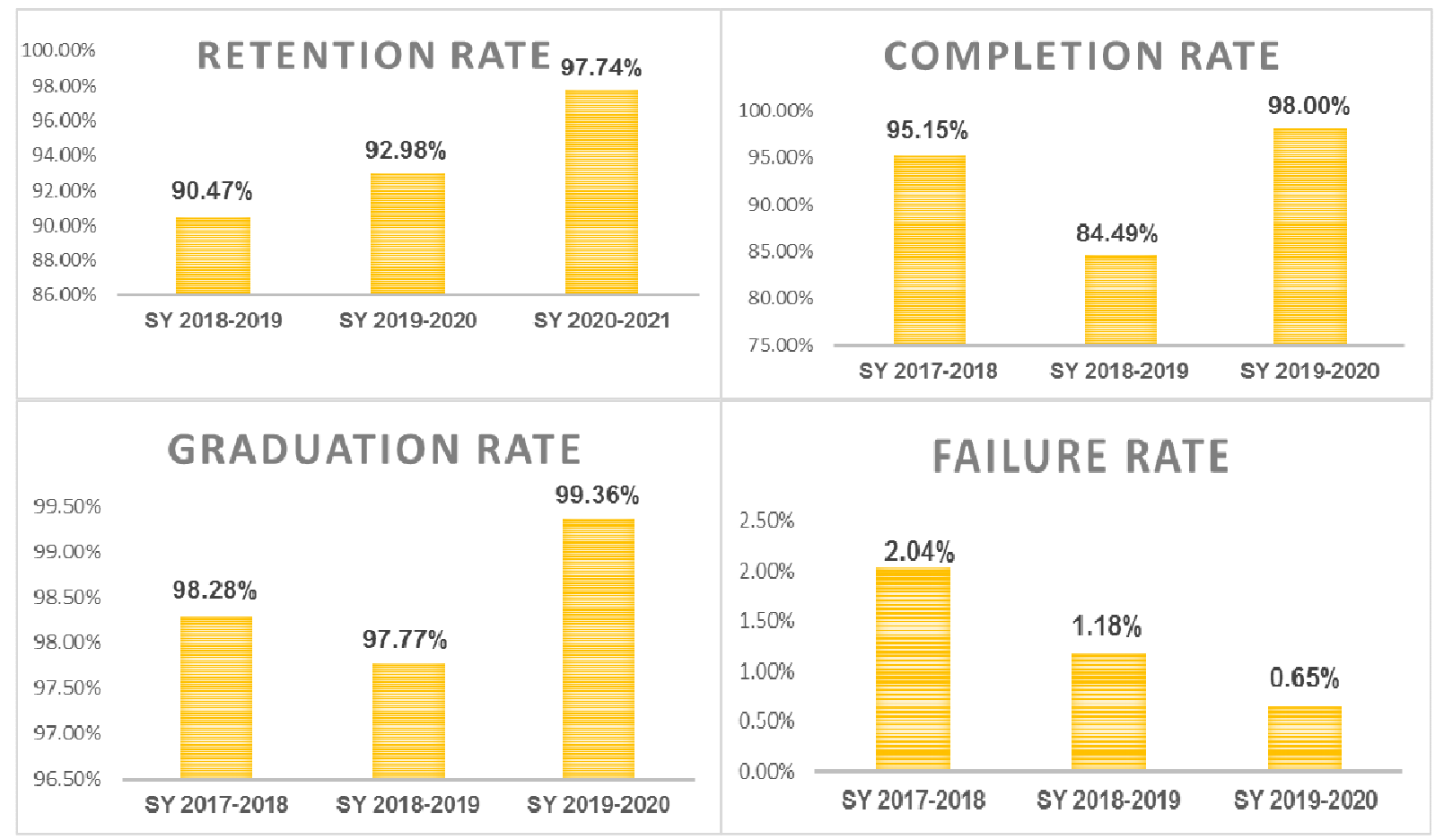

\subsection{Reflection}

With the implementation of the Project SAGIP, the spirit of "Shared Governance- Responsibility, Accountability, and Commitment" among teachers, school head, parents, and other stakeholders prevailed. As recorded, more homes were visited not just once but whenever necessary; ADM Program had also been strengthened that resulted to more cooperative rapport between the home and the school. 
Interventions and creative activities used in the implementation of Project SAGIP also paved way to promote positive behavior as we had increased in the number of student- awardees including Student of the Month (Grade 7-12), Perfect Attendance Awardees, and other special awards, and a total of 395 students were Academic Awardees (with honors, with high honors) by the end of the SY 2019-2020. The success of implementation of relevant programs and activities could also be attributed to the numerous achievements of our students as articulated in our School Report Card (SRC).

It is therefore recommended that the Guidance Office should continue using the Profiling and Initial Risk Assessment Tool for Children-at- Risk (DO 18, S. 2015). Also, relevant programs and projects to address the identified problems of student-at-risk under Project SAGIP should be continuously implemented for better KPI results in the present school year as deemed suited in the New Normal education.

\section{Action plan for continuous implementation of project SAGIP in the new normal education}

\begin{tabular}{|c|c|c|c|c|c|c|}
\hline Key Result Area & Objective & Strategies/ Activities & $\begin{array}{l}\text { Persons } \\
\text { Involved }\end{array}$ & Time Frame & $\begin{array}{l}\text { Expected } \\
\text { Outcome }\end{array}$ & Means of Verification \\
\hline $\begin{array}{l}\text { Establishing } \\
\text { Baseline Data of } \\
\text { Students-At-Risk } \\
\text { (SARDOs) }\end{array}$ & $\begin{array}{l}\text { Identify } \\
\text { SARDOs } \\
\text { Conduct of } \\
\text { Guidance } \\
\text { Profiling } \\
\text { Survey using } \\
\text { revised } \\
\text { Assessment } \\
\text { Tool (based on } \\
\text { DO 18,s.2015) }\end{array}$ & $\begin{array}{l}\text { Knowing the learners } \\
\text { through inclusion in } \\
\text { their Class Group Chat/ } \\
\text { Online Messaging } \\
\text { Conduct online PTA } \\
\text { Conference (by Grade } \\
\text { level) }\end{array}$ & $\begin{array}{l}\text { School } \\
\text { head, all } \\
\text { teachers } \\
\text { School } \\
\text { Head, } \\
\text { Guidance } \\
\text { Teachers } \\
\text { Teachers, } \\
\text { parents and } \\
\text { guardians }\end{array}$ & $\begin{array}{l}\text { First- } \\
\text { Second } \\
\text { Week of } \\
\text { October } \\
\text { Third Week } \\
\text { of October }\end{array}$ & $\begin{array}{l}\text { At-Risk } \\
\text { students were } \\
\text { identified } \\
\text { Parents or } \\
\text { guardians were } \\
\text { thoroughly } \\
\text { informed }\end{array}$ & $\begin{array}{l}\text { Profile of Students, } \\
\text { Class Adviser's Report, } \\
\text { Initial Risk Assessment } \\
\text { Result }\end{array}$ \\
\hline $\begin{array}{l}\text { Preparation of } \\
\text { the Remediation } \\
\text { Activities and } \\
\text { other Relevant } \\
\text { Programs }\end{array}$ & $\begin{array}{l}\text { Prepare } \\
\text { remedial } \\
\text { materials } \\
\text { Conduct } \\
\text { relevant } \\
\text { activities to } \\
\text { help SARDOs } \\
\text { adjust to the } \\
\text { New normal } \\
\text { education }\end{array}$ & $\begin{array}{l}\text { Online meeting with } \\
\text { Curriculum Head, Class } \\
\text { Advisers, and Subject } \\
\text { Teachers } \\
\text { Preparing Learning } \\
\text { Activity Sheets (LASs) } \\
\text { suited to the level of the } \\
\text { students-at-risk but } \\
\text { based on the prescribed } \\
\text { MELCs } \\
\text { Implementation of } \\
\text { other programs and } \\
\text { creative activities: } \\
\text { Teach One, Each One, } \\
\text { Online Bible Study, } \\
\text { Talent Showcase, GPP } \\
\text { sa Tahanan, and Peace } \\
\text { Education Integration } \\
\text { program }\end{array}$ & $\begin{array}{l}\text { Teachers } \\
\text { Teachers of } \\
\text { different } \\
\text { grade level } \\
\text { Key } \\
\text { Teachers, } \\
\text { SSG } \\
\text { Officers }\end{array}$ & $\begin{array}{l}\text { Fourth } \\
\text { Week of } \\
\text { October to } \\
\text { First Week } \\
\text { of } \\
\text { November } \\
\text { First Week } \\
\text { of } \\
\text { November }\end{array}$ & $\begin{array}{l}\text { Activity } \\
\text { Sheets } \\
\text { especially } \\
\text { prepared for } \\
\text { SARDOs were } \\
\text { distributed } \\
\text { Well-prepared } \\
\text { Action Plans } \\
\text { for programs/ } \\
\text { activities }\end{array}$ & $\begin{array}{l}\text { Availability of Remedial } \\
\text { materials like levelled } \\
\text { activities, colorful LASs } \\
\text { Action Plans for Programs } \\
\text { and Activities, printed } \\
\text { flyers and leaflets, Online } \\
\text { Information-dissemination } \\
\text { scheme }\end{array}$ \\
\hline $\begin{array}{l}\text { Implementation } \\
\text { of the } \\
\text { Remediation } \\
\text { Activities and } \\
\text { other Relevant } \\
\text { Programs }\end{array}$ & $\begin{array}{l}\text { Implement the } \\
\text { remediation } \\
\text { activities and } \\
\text { relevant } \\
\text { programs for } \\
\text { SARDOs }\end{array}$ & $\begin{array}{l}\text { School-wide } \\
\text { implementation using } \\
\text { online platforms, } \\
\text { distributing flyers, and } \\
\text { leaflets along with } \\
\text { LASs distribution }\end{array}$ & $\begin{array}{l}\text { School } \\
\text { head, } \\
\text { advisers, } \\
\text { subject } \\
\text { teachers, } \\
\text { SSG and } \\
\text { Linguisteen } \\
\text { Club }\end{array}$ & $\begin{array}{l}\text { First Week } \\
\text { of } \\
\text { November } \\
\text { onwards }\end{array}$ & $\begin{array}{l}\text { Remediation } \\
\text { activities and } \\
\text { relevant } \\
\text { programs were } \\
\text { conducted as } \\
\text { planned }\end{array}$ & $\begin{array}{l}\text { Accomplished } \\
\text { remediation activities, and } \\
\text { Feedback Form }\end{array}$ \\
\hline $\begin{array}{l}\text { Monitoring and } \\
\text { Evaluation }\end{array}$ & $\begin{array}{l}\text { Monitor and } \\
\text { evaluate the } \\
\text { implementation }\end{array}$ & $\begin{array}{l}\text { Assessment of students' } \\
\text { performance }\end{array}$ & $\begin{array}{l}\text { School } \\
\text { head, } \\
\text { advisers, } \\
\text { and subject } \\
\text { teachers }\end{array}$ & Year round & $\begin{array}{l}\text { Students' } \\
\text { performance } \\
\text { was assessed } \\
\text { and } \\
\text { effectiveness } \\
\text { of activities } \\
\text { being } \\
\text { conducted was } \\
\text { monitored }\end{array}$ & $\begin{array}{l}\text { Performance/ } \\
\text { Observation reports and } \\
\text { results of assessments }\end{array}$ \\
\hline
\end{tabular}


Manalo, H.

Acknowledgement - The researcher would like to extend her recognition and appreciation to the following persons who significantly contributed to the success of Project SAGIP: Guidance Teachers of Dagatan NHS:

Ma'am Juliana D. Magadia, Ma'am Marilou A. Javier, and Ma'am Rhona C. Binay; Prefects of Discipline: Ma'am Belen M. Buela, Sir Joel Briones, Sir Alvin Cordero; Class Advisers from Grade 7-12 during the SY 2019-2020; Record Officer Ma'am Rosemarie Carcole and ICT/LIS Coordinator Ma'am Reina Diane Bautista; SSG and Linguisteen Club family; Our very supportive Public Schools District Supervisor, Dr. Emiteria B. Villamor for always inspiring us to do more; Authors of the references used in this study; and Our dear parents, barangay officials, and other stakeholders who are our partners in implementing school policies, programs, projects, and activities.

\section{References}

Ary, D., Jacobs, L. C., \& Sorensen, C. (2010). Introduction to research in education. Cengage.

Cornell, D., Gregory, A., Huang, F., \& Fan, X. (2013). Perceived prevalence of teasing and bullying predicts high school dropout rates. Journal of Educational Psychology, 105(1), 138-149. https://doi.org/10.1037/a0030416

David, C. C., \& Albert, J. R. G. (2015). Recent trends in out of-school children in the Philippines. PIDS Discussion Paper Series, No. 2015-51. Quezon City: Philippine Institute for Development Studies.

Dupere, V., Leventhal, T., Dion, E., \& Crosnoe, R. (2014). Stressors and turning points in high school and dropout: A stress process, life course framework. Review of Educational Research, 85(4). https://doi.org/10.3102/0034654314559845

Savin-Baden, M., \& Major, C. (2013). Qualitative research: The essential guide to theory and practice. Routledge

Valkov, P. (2018). School dropout and substance use: Consequence or predictor? Trakia Journal of Sciences, 2 , 95-101. https://doi.org/10.15547/tjs.2018.02.004 